ARTICLE

DOI: $10.1057 /$ s41599-018-0133-5

\title{
The liquid politics of an urban age
}

\author{
Loan Diep ${ }^{1}$
}

\begin{abstract}
In fragile social and economic societies, water governance systems have rarely managed to meet everyone's needs, but rather misrecognised the demand of those excluded from decision-making structures. Across regions, underlying socio-political issues have often remained unaddressed on the basis that water scarcity is primarily caused by geo-climatic conditions. Exclusionary governance is one central driver to migratory patterns along with instabilities in political regimes. It is reflected in poor service provision and tends to perpetuate injustices. Several commitments of the New Urban Agenda (NUA) set objectives of universal and equitable water provision through multi-stakeholder involvement in urban planning processes. It thereby demonstrates efforts deployed towards 'good governance' for transparent, accountable and participatory decision-making. However, several studies have pointed out the questionable role of citizens in NUA. Building on their argument, the present article reflects on exclusionary patterns that the NUA aims to tackle and the mechanisms it proposes to achieve this. This article aims to highlight how power relations in water governance produce and reproduce exclusion in access, such as through population movements. It questions how NUA envisions water governance structures based on collaboration between multiple stakeholders in different contexts, and highlights the need to scrutinise the people-centric language adopted in its commitments. With references to water politics from Latin America and the Middle East and North Africa (MENA) region, it adopts a political ecology approach looking at questions of inclusivity for marginalised groups and discusses approaches for the active involvement of these people in water governance models.
\end{abstract}

\footnotetext{
${ }^{1}$ University College London, London, UK. Correspondence and requests for materials should be addressed to L.D. (email: Ioan.diep.10@ucl.ac.uk)
} 


\section{Introduction}

ecognising the growing challenges regarding so-called 'water scarcity' in cities, the New Urban Agenda (NUA) makes multiple commitments regarding water resources in terms of sustainable and just management, as well as in distribution (United Nations, 2017). However, the NUA's framework for governance and its implications need to be scrutinised carefully. Roberts (2008) argues that water governance structures often portray a reductionist concept of the city, and deny political disputes and inequalities in producing problems and perpetuating failures. Ioris $(2012 ; 2016)$ adds to this that the city cannot be understood without reference to the political struggles and alliances that play a critical part in its own organisation.

Aligning with these positions, this article seeks discussions on past and future implications of water governance challenges in cities in light of the NUA. In Part 2, it advocates for the need to tackle dominance and exclusion in water governance. It argues that water scarcity issues are exacerbated by socio-political oppressions rather than climate and/or demographic conditions, while population movements makes these linkages more complex. In Part 3, the paper uses historical water management models to reflect on the potential of the NUA to foster changes in governance structures, especially in regard to multi-stakeholder approaches. It then explores how patterns of exclusion can be broken through collaborative processes in order to structurally address these issues. References to Latin America and the Middle East and North Africa (MENA) region are made to illustrate the need to envision roles for water users as right-bearers in contextspecific water governance systems.

'Water governance' is defined here as the institutional processes involving different actors and networks, and setting rules for them. As opposed to a focus on outcomes (on policies for example), governance is explored in terms of processes of dialogue, negotiations and the way these evolve with time. Such processes would, in principle, consider different positions and negotiate trade-offs. 'Water management' is defined as the application of governance rules and the operationalisation of policies with the practical aspects of water allocation, preservation and restoration (Hill, 2013).

The text refers to 'citizens' and 'communities' while attempting to avoid homogenisation of groups. It argues that understanding social, cultural and political diversities is crucial to recognise the variety of people's needs, the conditions in which these are unmet, and the political structures in which they are claiming them. This is particularly important in the context of international population movements, where the term 'citizen' may be no longer relevant to refer to inhabitants of a particular city or town, without bearing the same legal rights as natives or naturalised individuals, but who remain legitimate in claiming unmet basic needs. Inclusive governance refers to the active involvement of stakeholders who hold different interests and responsibilities in institutional decision-making systems, and particularly that of marginalised populations.

\section{Water as a mirror of exclusion}

A most contested liquid. Water has various functions and values according to different people. Considered as a biophysical necessity for both humans and ecosystems, a religious symbol, an aesthetic reference, an economic input and a public service, water is source of conflicts for ownership and management (Bakker, 2011). Essential to all societies but limited in quantity and impossible to replace, water requires sharing arrangements. Complex governance systems for water common resources are thus put in place; in principle, to meet everyone's most basic needs.
Building on Miranda et al. (2011) four principal discourses on water management are identified here:

1. To those considering water as an economic good or a commodity (i.e., with an economic value), water governance should be centred on market principles and usually involve the private sector (see for example World Bank, 2005 and Marin, 2009);

2. Where water is valued as a social good or human right, the social aspects of governance are primordial and involve access to resources and services by all. This view emphasises the need to actively involve the civil society in decisionmaking;

3. Where water is not only considered as a right to humans but also to other living beings, it can be referred to as a socioecological good. In water governance, this is translated into the fulfilment of public interests whilst attempting to include nature as an entity with its own right;

4. Other consider water as a sector. This discourse emphasises the need for efficient management of water services, often with a river basin management approach (see for example IWA, 2016). This proposes the most hybrid approach, based on the argument that the above views on water management are not mutually exclusive. It integrates economic and social concerns with a focus on management as a supply and demand equation. It has more recently embraced the notion of environmental services to preserve upstream water for downstream services.

Divergence of views constitutes the bases of water governance disputes, where government agencies and political parties, civil organisations and NGOs adhere to different principles, values, culture and interests (Rogers and Hall, 2003). Opinions, stakes and discourses may obviously vary from one actor to another within one entity, but disputes and competition between groups serving conflicting interests remains a fundamental challenge to address. With the existence of such diversity of views, the challenge lies in defining common objectives and in establishing management models upon these objectives.

In addition, geo-climatic constraints lead people to organise and enter into competition for water appropriation and usage. The transboundary aspect of resources makes disputes occur at multiple scales ('hydro-political tensions'), from the local to the global (De Stefano et al., 2017). Therefore, physical characteristics determine social interactions, from which relations of cooperation or domination emerge. These provide a basis for creation of the institutional and managerial systems that articulate water governance objectives. Where disparities occur, the struggle for access and control leads to the emergence of power holders. As conceptualised by Swyngedouw (2004, p. 4), flows of power evolve in the same direction as urban water circulation, thereby determining the direction of "the right to water".

As such, water captures, embodies and re-produces sociopolitical processes. In unbalanced power relationships, elites take decisions for water management structures and systems. Political ecologists argue that these decisions rarely reflect all stakeholders' interests, or worse, oppress those of the marginalised. Top-down decision-making planning privileging 'winners' run the risk of reinforcing the exclusion of 'losers'. This is particularly true in vertical structures influenced by neoliberal, post-colonial and market globalisation approaches (Loftus, 2009; Ioris, 2016).

Water governance and population movements. Causal links between water access, climate change, population displacements, institutional capacities, and governance systems are complex to 
identify. For example, do people whose economic income depends on climate conditions migrate as a result of more frequent and intense droughts, or because institutions are not able to put in place systems for more efficient and more equitable water distribution? Discourses used by decision-makers and found in the media and non-governmental reports sometimes use climate change, population movements or economic crises to justify failures in water service provision. This depolitisation of water issues runs the risk of perpetuating oppression by masking sociopolitical factors. The two following parts attempt to revisit the causalities between water governance, migration and displacement (urban-rural and from city to city, nationally and internationally), and to highlight needs to identify discourses that hide patterns of exclusion.

The World Resources Institute (2016; in SIWI, 2016) states that water scarcity is cited with increasing frequency as a significant multiplying factor prompting migration. In fact, more and more studies recognise people migrate as a result of deterioration of their social and environmental conditions, and not solely because they are in search of better social and economic opportunities (EJF, 2017; Miletto et al., 2017; Boano et al., 2008). Multiple historical cases therefore show that migrants pulled by urban areas where they seek better opportunities to meet their needs and beyond could in fact having been pushed by poor conditions of services where they come from, and not only in contexts of forced displacement.

On urban-rural migration, Tacoli et al. (2015) differentiate groups of migrants: for example those moving permanently for employment and/or education purposes, those moving on a seasonal basis and who usually form the poorest rural groups, and those who lose their livelihoods due to escalating risks. The latest tend to make displacements permanent due to the perception of future risks, including climate-related risks (Warner, 2010). Toli (2016) reports that in MENA, one of the world's driest regions, inter-regional migration of the youth particularly occurs from rural to urban settings. Those with sufficient financial means leave their country by crossing borders but climate-related migratory fluxes mainly take place within countries. For people whose income depends largely on water, for example in agriculture, unreliable water supply leads to the loss of their jobs because their income stability is compromised (Miletto et al., 2017). To people who have few adaptation options in situ, migration is a coping strategy ensuring remittances for the survival of families.

Droughts tend to be unquestionably perceived as a direct contributing factor for migration, and studies have often failed to unpack socio-political drivers inherent to failing governance systems (Owain and Maslin, 2018). Political discourses presenting drought as a cause of migration contribute to the 'naturalisation' of scarcity, failing to account for the institutional and managerial issues that explain why marginalised populations lack access to water (Kaika, 2003). That means issues of water access are attributed to 'natural' causes, when in fact water scarcity is a combination of physical, infrastructural, institutional and political challenges. Water scarcity discourses overlook underlying social struggles and failed cooperation in water management. As argued by Bulkeley et al. (2014) climate change, as a risk multiplier, accelerates the injustice trend and adds a complex variable to the equation.

Political waves and ripple effects. The exclusionary cycle rarely ends with migration. If bad water governance is (at least in part) causing displacement, it can also lead to further issues at the migration destination. In many cities, migrants share similar disadvantages to the existing urban poor. Tacoli et al. (2015) argue this exclusion is directly related to the types of settlements they live in. Migrants who live in worst-quality informal settlements (for example temporary structures on public land on the urban periphery), have limited access to public infrastructure and services (Scott, 2013; Murillo, 2014). Despite the demonstrated benefits of inclusive policies, migrants are often unfairly blamed for increasing poverty, while they actually face further or new exclusion patterns.

There is a real policy challenge for local and national governments which may be unable or unwilling to provide services to those most in need. International laws and conventions may not be effectively enforced and ensure displaced and vulnerable populations' protection. In extreme cases of climateinduced or conflict-induced displacement, the international law has not yet been conferring clear rights to people fleeing home. Refugees and internally displaced populations, as opposed to migrants, are forced to move away from home. Ongoing and complex debates occur on how the 1951 Geneva Convention for political refugees and the UN Refugee Convention could legally recognise the concept of 'climate refugee' and thereby help displacement challenges to be addressed within an institutional structure. The principle of non-refoulement - where states are forbidden to oblige migrants to return to life-threatening situations - could apply, but only to specific situations (Fernández, 2015).

The NUA makes a commitment in Article 28 to "ensure full respect for the human rights of refugees, internally displaced persons and migrants, regardless of their migration status". But there is no clear definition in NUA to clarify what the terms "refugees", "internally displaced persons" and "migrants" entail. While so-called climate-induced displacements are closely linked to social and political factors, the recognition, definition and characterisation of such drivers in legal tools poses significant problems. Besides, as a non-binding agreement, NUA does not provide legal obligation for action. Such debates will increase in complexity if causes of displacement remain ambiguous in political discourses. This is at the risk of maintaining status-quo in decision-making where oppressions are produced and reproduced in traditional governance models, in which power relations are poorly articulated.

\section{Synergies in water governance}

Models and ideologies. The 1960s marked the period where mass production and consumption started to be questioned. This led to ideologies of societal response to coercive force applied by the state to prevent the tragedy of environmental resource destruction. Inspired by Hobbes' Leviathan, this reflected a liberal attitude towards governance, where governments were required to intervene on the control of natural resources, including water (Hardin, 1968; Ostrom, 1990). Centralised control and regulation were particularly applied in low-income countries. However, state-led water governance appeared to face crucial challenges in many of them. Insufficient coverage rates, under-investment, deterioration of infrastructure and unresponsiveness to the needs of the poor widened social inequalities (Bakker, 2011).

The ideology of a 'command and control' hierarchal system acting in the interest of society faded and was replaced by freemarket liberal ideologies. In this regime, the state's role is to guarantee free operation of market forces. Proponents of privatisation have asserted that where the government had failed, the private sector could perform better by providing more finance and expertise. In the water sector, that was assuming that privately run utilities would ensure efficiency while seeking maximised commercial returns. With the perspective of 'water as a commodity', proponents claimed that treating water as an 
economic good could also facilitate the implementation of environmentally-friendly regulations (McCarthy and Prudham, 2004)

In line with neoliberal principles emerging in the 1980s, a global wave of privatisation took place in the water sector. Rooted in similar objectives of performance and above all, investment, Public-Private Partnerships (PPPs) became common arrangements. International Finance Institutions (e.g., World Bank, International Monetary Fund) were particularly advocating for PPPs, which led to structural reforms being adopted by governments worldwide. These were driven by conditionalities attached to loan agreements with funders (e.g. structural adjustment programmes).

In Latin America, many countries adopted these strategies following the oil crisis. Large-scale water infrastructure projects in Peru, for example, were established by the national government in partnership with foreign companies which would gain control on water extraction, transport and distribution mechanisms (Salazar, 2011). However poor regulatory structures and flawed contract negotiations meant that privatisation projects and PPPs were carrying high investment risks. Coverage and tariffs would privilege specific urban areas, typically at the expense of the low-incomes. Because of a lack of result in establishing an accessible and sustainable system for water distribution protests rose across the region. Neoliberal approaches became strongly rejected, particularly by those considering water as a human right should be free of charge, and disputing the impacts of privatisation on equity (Davis, 2005; Harvey, 2005).

The exclusion of citizens from decision-making processes has been historically recurrent in governance systems. Much criticism has been addressed to state hierarchies and market systems for their governing methods being imposed on civil society without cooperation. Paternalistic and undemocratic practices have involved the exercise of power by political and economic actors who have sought to define the ends and means to be pursued by the society. The race for large-scale infrastructure and poorly planned network extensions required high capital costs that were difficult to meet as populations could not afford to pay for services associated to such investment. In Latin America, water privatisation have caused issues which extended beyond the water sector, from corruption to forced displacement of indigenous and black populations, and led to social struggle (Castro, 2008).

The new urban agenda: a change catalyst?. As socio-political problems water challenges require socio-political solutions. By tackling exclusive patterns and focusing on collaboration, then conflicts, population movements and further issues they entail can be minimised. The NUA recognises that issues in water supply and access go beyond ecological resource and physical infrastructure management. It adopts what appears as an inclusive discourse and acknowledges that equitable and affordable access to water is a right and need that requires particular attention to the vulnerable, and must be achieved through the elimination of legal, institutional, socio-economic and physical barriers.

Caprotti et al. (2017) warn against the reductionist approach and numerous assumptions made in the NUA, for example on the states' capacities to deliver on multiple commitments. Satterthwaite (2016) reminds us of the importance of keeping NUA coherent, and more importantly advocates for more power transfer to actors (government and non-government actors) at local level.

In what concerns water nevertheless, NUA advocates that the sector requires stronger utilities as a necessary step to tackle inequalities in access to water, and commits in addressing this in Article 120:

"We will work to equip public water and sanitation utilities with the capacity to implement sustainable water management systems, including sustainable maintenance of urban infrastructure services, through capacity development, with the goal of progressively eliminating inequalities and promoting both universal and equitable access to safe and affordable drinking water for all and adequate and equitable sanitation and hygiene for all."

In this aspect, NUA proposes a utility-centric solution (whether utilities are privately/semi-privately run, public, and local, national or international) and makes the confusing assumption that this will integrate people-centric solutions.

Furthermore, the document makes explicit commitment towards integrated water resources planning and management through the participation of multiple stakeholders including that of communities. Article 72 reads:

"We commit ourselves to long-term urban and territorial planning processes and spatial development practices that incorporate integrated water resources planning and management, considering the urban-rural continuum on the local and territorial scales and including the participation of relevant stakeholders and communities."

Despite the questionable distinction between "communities" and "relevant stakeholders" such as in Article 72, citizens hold an important place throughout the agenda, which could be translated as an interest in achieving social justice in urban areas. But the appropriation of people-centric language without genuine inclusive intension runs the risk of re-producing exclusive patterns once again. On this recurrent trend, Ioris (2016, p. 279) argues: "one main problem is that public participation has been appropriated by the same agencies that in the past promoted highly centralised, disjointed and politically asymmetric administration".

Caprotti et al. (2017, p. 9) point out the ambiguous active role of urban citizens in NUA and argue that this consists more in envisioning their role according to institutional plans rather than as citizens in their own rights. For example, they highlight the way "digital citizens" are being produced behind inclusionary discourses, and this in order to participate in data collection mechanisms for metrics-driven urban policies and politics. In fact, this contrasts with the participation of citizens for the sake of genuinely understanding their desires and aspirations.

While there is mainstream acknowledgement in the literature that governance should be shaped with multi-stakeholder approaches, it is less obvious to define the way this should occur. NUA reflects this but remains rather silent on the way people can be included. According to Hill (2013) 'governance' needs to involve state and non-state actors, both private and public, and is thus broader and more inclusive than 'government', as the state autonomous authority. Governance must therefore transcend state hierarchies and market systems (Amin, 1997).

In modern societies where dynamics are increasingly complex, the question of 'what entity should take decisions to govern water?' is rather obsolete. Good governance is often theoretically described as a balanced partnership between the state, the market and the civil society in order to achieve accountable, transparent, participatory and decentralised decision-making (UNDP, 2011). However in reality, governance is fundamentally characterised by unbalanced power relations (Griffin, 2013). Instead of seeking symmetrical relationships, governance structures would rather need to enable dynamics to exist, through which contestation can occur, be heard and responded to. The following sections 
question what forms of partnerships can be envisaged to manage water inclusively.

Envisioning inclusive approaches in Latin America. In view of recurrent patterns of monopolisation in various water governance systems, there is a need to envision an active role for people to reclaim their right to water, through inclusive governance. Building on Schlosberg (2009) who explores three dimensions of environmental justice, namely distribution, recognition and participation, Hofmann (2017, p. 71) argues that "focusing on increased distribution of water and sanitation services without enhancing recognition of the urban water-poor only partially addresses the issue". Distribution will be meaningful if the nature, diversity and cultural contextualisation of needs are appropriately recognised. Recognition in this sense, also acknowledges the political construction of domination, and though this process, it relieves both social oppression and distributional inequity.

The recognition of the lack of collective voice in decisionmaking around water governance also invites for participation by these same excluded populations. Participation has been widely advocated for in the governance literature, around the basis that it can support more effective and open social structures (Batchelor, 2007). Although a complex notion that has been defined in multiple manners, public participation is considered here as the decision-making process in which the public is integrated through active engagement, for example through direct negotiations with representatives and through the co-design of strategies. As such it is more powerful when it enables dialogue, rather than for the ultimate goal of developing policies. In addition to fulfilling people's rights, participation should assure accountability and transparency through synergetic relationships between stakeholders.

Across Latin American countries, market-oriented strategies have been strongly rejected by the civil society. Searching for an alternative to PPPs, Venezuela, Colombia and Bolivia are some of the states having put in place what is referred to as 'water coproduction', with formal arrangements between state agencies and organised groups of citizens (Joshi and Moore, 2004; LlanoArias, 2015). Venezuela enacted a national policy in 2001 to formalise existing local water committees, the Mesas Técnicas del Agua. The Act established a coherent scheme that addressed existing clashes between authorities, which were causing deficiency of service, illegal taps and lack of pro-poor policies. With the 2011 system, the state-owned utility holds financial obligation, while the community intervenes at all stages of provision: needs assessment, diagnosis with professionals, design of rehabilitation and expansion projects, monitoring and maintenance. This was recognised as a major improvement for service coverage, but also for the possibility given to communities exercise rights and duties. In $2008,93 \%$ of the national urban population had access to water supply (Allen et al., 2017).

For many experts, water co-production has enabled citizens to augment capacity to negotiate with the state, and increase opportunities for wider democratic projects (Bovaird, 2007). This has increased potential to find alternatives in the way water is managed and services delivered (Mitlin, 2008). However, others have questioned the real impacts of water co-production if solely sought as a practical mechanism for water delivery, and warned about state entities devolving risk and responsibilities to people (Boyle and Harris, 2009). The extent to which these governance models can build local-level empowerment and be reproduced in a manner it leads to transformative agendas depends on many factors, including that of the underpinning incentives of 'coproducers'. On the case of Venezuela, Allen et al. (2017) explain improved service coverage has alleviated thousands of people from water poverty through service co-production, but this was possible because of a long democratic struggle and a strong commitment from the state.

Envisioning inclusive approaches in MENA. The involvement of the civil society in decision-making processes can take multiple forms and remains of course, dependent on the social and political context. In MENA countries where socio-political structures have evolved with their own history, people's involvement in water governance requires fundamentally different approaches to inclusive governance than in Latin American countries. The diversity of factors causing water issues is particularly complex in MENA as water is simultaneously a cause of political conflict, a mirror of institutional incapacity and a weapon of war resulting in migration (e.g., in Syria; De Châtel, 2014).

In Jordan and Lebanon, where water has been predominantly valued as an economic good, the governments have been seeking a growing involvement from the private sector to address multiple challenges (CDR, 2015; MWI, 2015, 2016). In contexts of water shortages within country boundaries and where resource management is not keeping up with consumption patterns, refugee influxes from Syria have added complexity to the political picture of service provision mechanisms. Tensions between refugees and underserved host communities, added to resentment towards utilities, have made relationships between people and institutions in charge of water provision more difficult. These have further affected water systems in terms of connections, payments and cost-revenue, frequency of supply, and network maintenance (Diep et al., 2017).

Aiming at creating platforms for dialogue based on social cohesion, a growing number of international and local NGOs, have acted as bridges between stakeholders. As part of an aim to ensure accountability and build trust, they have mediated relationships between state-owned utilities in charge of water provision and water users, including both refugees and host communities who remain underserved with public services. This has aligned with the perspective of shifting from sectorial approaches focused on water production, to demandmanagement approaches. In Lebanon, this has supported utilities' understanding of and response to local needs, and people's willingness to subscribe to the network (GVC, 2016).

In structures where people have growing voice in negotiations, or have a growing active role in decision-making processes, stakeholders' relationship is crucial to optimise the sustainability and inclusivity aspects of governance. The clear distribution of roles also helps distributing power dynamically in negotiations and operations. Stronger local governance as stated in NUA, with a growing role for people, should not lead to lower responsibilities for state entities at national and local level and the private sector, but a public and private involvement where roles are redefined in a way it gives space to the civil society. Good governance would mean that state's responsibilities are passed onto actors originating from the democratic arena and local actions articulated through alliances with policy instruments.

\section{Conclusion}

Water governance requires mechanisms that work with power dynamics, rather than a sole focus on production through infrastructural development. As cities concentrate a complicated mix of factors causing water challenges, it is more and more important to highlight these dynamics in order to establish systems that will work with them. The NUA attempts to make a coherent account of these needs. The challenge lies in going over general statements and one-size fit all solutions, and in activating these agendas in various context. The "participation of relevant 
stakeholders and communities" (United Nations, 2017, p. 21) will require different governance arrangements in different sociopolitical contexts. The re-definition of power relations, answers to people's needs and inequality reduction will however depend on the nature of the negotiation strategies deployed.

Without political willingness and mutually set agreements, communication and collective action will not mechanically result in just and equitable outcomes. As highlighted by Batchelor (2007), questions of power inherently remain in negotiation processes, even when third parties are acting as mediators. Identifying those who benefit and those who suffer from decisions, even when taken from collaborative processes, is therefore crucial to avoid masked abuses of power. This starts with explicit recognition that social structures for access and control need to be reconstructed in order to make space for those who have been victims of repeated exclusion patterns. As politics require to evolve with socio-environmental dynamics ("liquid politics"), then the goal to meet when activating the New Urban Agenda for water governance, is to build on existing systems with inclusionary mechanisms.

Received: 16 February 2018 Accepted: 29 May 2018

Published online: 26 June 2018

\section{References}

Allen A, Walnycki A, von Bertrab É (2017) The Co-production of Water Justice in Latin American Cities. In: Allen A, Griffin L, Johnson C(eds) Environmental Justice and Urban Resilience in the Global South. Palgrave Macmillan, New York, pp 175-194

Amin A (1997) Beyond market and hierarchy: interactive governance and social complexity. Elgar, Cheltenham

Bakker K (2011) Commons versus commodities: political ecologies of water privatisation. In: Peet R, Robbins P, Watts J (eds) Global Political Ecology. Routledge, London, pp 347-370

Batchelor C (2007) Water governance literature assessment. International Institute for Environment and Development, London. http://pubs.iied.org/G02523/? $\mathrm{a}=\mathrm{C}+$ Batchelor

Boano C, Zetter R, Morris, T (2008) Environmentally Displaced People: Undertanding the Linkages between Environmental Change, Livelihoods and Forced Migration, University of Oxford Refugee Studies Centre

Bovaird T (2007) Beyond engagement and participation: user and community coproduction of public services. Public Adm Rev 67(5):846-860. https://doi. org/10.1111/j.1540-6210.2007.00773.x

Boyle D, Harris M (2009) The challenge of Co-Production-How equal partnerships between professionals and the public are crucial to improving public services. NESTA, London. https://doi.org/10.1111/etap.12092

Bulkeley H, Edwards GAS, Fuller S (2014) Contesting climate justice in the city: examining politics and practice in urban climate change experiments. Glob Environ Change 25(1):31-40. https://doi.org/10.1016/j.gloenvcha.2014.01.009

Caprotti F, Cowley R, Datta A, Broto VC, Gao E, Georgeson L et al. (2017) The New Urban Agenda: key opportunities and challenges for policy and practice. Urban Res Pract 10(3):367-378. https://doi.org/10.1080/ 17535069.2016 .1275618

Castro JE (2008) Water struggles, citizenship and governance in Latin America. Development 51(1):72-76. https://doi.org/10.1057/palgrave.development. 1100440

CDR (2015) Progress Report. Council for Development and Reconstruction, Beirut. http://www.cdr.gov.lb/eng/progress_reports/pr102015/index.asp

Davis I (2005) Private-sector participation in the water and sanitation sector. Annu Rev Environ Resour 30:145-183

De Châtel F (2014) The Role of Drought and Climate Change in the Syrian Uprising: Untangling theTriggers of the Revolution. Middle Eastern Studies 50(4):521-535. https://doi.org/10.1080/00263206.2013.850076

Diep L et al (2017) Water, crises and conflict in MENA: how can water service providers improve their resilience? International Institute for Environment and Development, London. http://pubs.iied.org/pdfs/10846IIED.pdf

EJF (2017) Beyond borders: our changing climate-its role in conflict and displacement. http://www.ncbi.nlm.nih.gov/pubmed/21263253

Fernández MJ (2015) Refugees, climate change and international law. Force Migr Rev 49(May):42-43
Griffin L (2013) Good Governance, scale and power: a case study of North Sea fisheries. Routledge, London

GVC (2016) Cost recovery and demand management in Lebanese Water Sector. GVC, Zahle

Hardin G (1968) The tragedy of the commons. Science 162(3859):1243-1248

Harvey D (2005) The new imperialism. Oxford University Press, Oxford

Hill M (2013) Climate change and water governance. In: Advancesin Global Change Research. Vol. 54. Springer Netherlands, Dordrecht, pp 17-29

Hofmann P (2017) 'Institutional Discourses on Urban Water Poverty, Considering the Example of Dar es Salaam, Tanzania: Reconciling Justice and Resilience'. In: Allen A, Griffin L, Johnson C (eds) Environmental Justice and Urban Resilience in the Global South. Palgrave Macmillan, New York

Ioris AaR (2012) The geography of multiple scarcities: urban development and water problems in Lima, Peru. Geoforum. Elsevier Ltd, 43(3):612-622. https://doi.org/10.1016/j.geoforum.2011.12.005

Ioris AAR (2016) Water and the (All Too Easy) promised city: a critique of urban water governance. In: Bell S, et al. (eds) Urban Water Trajectories. Springer International Publishing, Switzerland

IWA (2016) Water utility pathways in a circular economy. http://www.iwanetwork.org/wp-content/uploads/2016/07/IWA_Circular_Economy_screen. pdf. Accessed 17 January 2018

Joshi A, Moore M (2004) 'Institutionalised co-production: unorthodox public service delivery in challenging environments'. J Dev Stud 40(4):31-49. https:// doi.org/10.1080/00220380410001673184

Kaika M (2003) Constructing scarcity and sensationalising water politics: 170 days that shook Athens. Antipode 35(5):919-954. https://doi.org/10.1111/j.14678330.2003.00365.x

Llano-Arias V (2015) Community knowledge sharing and co-production of water services: two cases of community aqueduct associations in Colombia. Water Altern 8(2):77-98

Loftus A (2009) Rethinking political ecologies of water. Third World Q 30 (5):953-968. https://doi.org/10.1080/01436590902959198

Marin P (2009) Public-Private Partnerships for Urban Water Utilities: a Review of Experiences in Developing Countries. No. 8. https://openknowledge. worldbank.org/bitstream/handle/10986/2703/53017.pdf?sequence=6 Accessed 15 December 2017.

McCarthy J, Prudham S (2004) Neoliberal nature and the nature of neoliberalism. Geoforum 35(3):275-283. https://doi.org/10.1016/j.geoforum.2003.07.003

Miletto M et al. (2017) Migration and its interdependencies with water scarcity, gender and youth employment. Paris. http://unesdoc.unesco.org/images/ 0025/002589/258968E.pdf.

Miranda L, Hordijk M, Torres Molina RK (2011) Water governance key approaches: an analytical framework. Chance2sustain, Lima.

Mitlin D (2008) With and beyond the state-co-production as a route to political influence, power and transformation for grassroots organizations. Environ Urban 20(2):339-360. https://doi.org/10.1177/0956247808096117

Murillo F.(2014) World Migration Report 2015: Migration and Urbanization Paths: reshaping the Human Geography of Latin America and the Caribbean.

MWI (2015) Annual Report 2015. Amman. http://www.mwi.gov.jo/sites/en-us/ AnnualReports/Reportwater-2015.pdf Accessed 23 January 2017

MWI (2016) National Water Strategy of Jordan, 2016-2025. http://www.mwi.gov. jo/sites/en-us/HotIssues/StrategicDocumentsofTheWaterSector/ NationalWaterStrategy(2016-2025)-25.2.2016.pdf Accessed 23 January 2017

Ostrom E (1990) Governing the commons: the evolution of institutions for collective action, political economy of institutions and decisions. In: James E, Douglass C (eds) Cambridge University Press, Cambridge

Owain EL, Maslin MA (2018) Assessing the relative contribution of economic, political and environmental factors on past conflict and the displacement of people in East Africa, Palgrave Communications. Springer US

Roberts A (2008) Privatizing social reproduction: the primitive accumulation of water in an era of neoliberalism. Antipode 40(4):535-560. https://doi.org/ $10.1111 / j .1467-8330.2008 .00623 . x$

Rogers P, Hall AW (2003) Effective Water Governance. Vol. 7, Global water partnership

Salazar J (2011) Private Sector Participation (PSP) in the Peruvian drinking water sector. Cape Town. https://www.yumpu.com/en/document/view/6722988/ psp-in-the-peruvian-drinking-climate-investment-funds

Satterthwaite D (2016) A new urban agenda? Environ Urban 28(1):3-12. https:// doi.org/10.1177/0956247816637501

Schlosberg D (2009) Defining environmental justice: theories, movements and nature. Oxford University Press, Oxford

Scott P (2013) Dealing with land tenure and tenancy challenges in water and sanitation services delivery. Water and Sanitation for the Urban Poor, London

SIWI (2016) Water, migration and how they are interlinked. Vol. 27. Stockholm International Water Institute, Stockholm

De Stefano L et al. (2017) Assessment of transboundary river basins for potential hydro-political tensions. Glob Environ Change 45:35-46. https://doi.org/ 10.1016/j.gloenvcha.2017.04.008 
Swyngedouw E (2004) Social power and the urbanization of water. Oxford University Press, New York

Tacoli C, McGranahan G, Satterthwaite D (2015) Urbanisation, rural-urban migration and urban poverty. International Institute for Environment and Development, London. http://pubs.iied.org/10725IIED Accessed 6 January 2018

Toli K (2016) The New "Water-Employment-Migration" Nexus. http://www. revolve-water.com/new-water-employment-migration-nexus/ Accessed 10 Feb 2018

UNDP (2011) Governance principles, institutional capacity and quality. UNDP, New York

United Nations (2017) New Urban Agenda, in United Nations Conference on Housing and Sustainable Urban Development. Quito.

Warner K (2010) Global environmental change and migration: governance challenges. Global Environmental Change 20(3):402-413

World Bank (2005) Approaches to private participation in water services. The World Bank, Washington

\section{Data availability}

Data sharing not applicable to this article as no datasets were generated or analysed during the current study.

\section{Acknowledgements}

This article was written as part of a research supported by EPSRC.

\section{Additional information}

Competing interests: The author declares that they have no competing interests.

Reprints and permission information is available online at http://www.nature.com/ reprints

Publisher's note Springer Nature remains neutral with regard to jurisdictional claims in published maps and institutional affiliations.

\section{(c) (1)}

Open Access This article is licensed under a Creative Commons Attribution 4.0 International License, which permits use, sharing, adaptation, distribution and reproduction in any medium or format, as long as you give appropriate credit to the original author(s) and the source, provide a link to the Creative Commons license, and indicate if changes were made. The images or other third party material in this article are included in the article's Creative Commons license, unless indicated otherwise in a credit line to the material. If material is not included in the article's Creative Commons license and your intended use is not permitted by statutory regulation or exceeds the permitted use, you will need to obtain permission directly from the copyright holder. To view a copy of this license, visit http://creativecommons.org/ licenses/by/4.0/.

(C) The Author(s) 2018 